\title{
Protective Role of Intracellular Superoxide Dismutase against Extracellular Oxidants in Cultured Rat Gastric Cells
}

\author{
Hideyuki Hiraishi, *3 Akira Terano,' Tsuneaki Sugimoto,' Takashi Harada,' Mahnaz Razandi, * and Kevin J. Ivey ** \\ * Department of Medicine, Veterans Affairs Medical Center, Long Beach, California 90822; ${ }^{\ddagger}$ University of California, Irvine, California \\ 92717; $\$$ Second Department of Internal Medicine, Dokkyo University School of Medicine, Tochigi 321-02 Japan; and \\ 'Second Department of Internal Medicine, Faculty of Medicine, University of Tokyo, Tokyo 113, Japan
}

\begin{abstract}
We examined the role of intracellular superoxide dismutase (SOD) as an antioxidant by studying the effect of diethyldithiocarbamate (DDC) on extracellular $\mathrm{H}_{2} \mathrm{O}_{2}$-induced damage in cultured rat gastric mucosal cells. ${ }^{51} \mathrm{Cr}$-labeled monolayers from rat stomachs were exposed to glucose oxidase-generated $\mathrm{H}_{2} \mathrm{O}_{2}$ or reagent $\mathrm{H}_{2} \mathrm{O}_{2}$, which both caused a dose-dependent increase in ${ }^{51} \mathrm{Cr}$ release. DDC dose-dependently enhanced ${ }^{51} \mathrm{Cr}$ release by hydrogen peroxide, corresponding with inhibition of endogenous SOD activity. This inhibition was not associated either with modulation of other antioxidant defenses, or with potentiation of injury by nonoxidant toxic agents. Enhanced hydrogen peroxide damage by DDC was significantly prevented by chelating cellular iron with deferoxamine or phenanthroline. Inhibition of cellular xanthine oxidase (possible source of superoxide production) by oxypurinol neither prevented lysis by hydrogen peroxide nor diminished DDC-induced sensitization to $\mathrm{H}_{2} \mathrm{O}_{2}$. We conclude that (a) extracellular $\mathrm{H}_{2} \mathrm{O}_{2}$ induces dose dependent damage to cultured gastric mucosal cells; (b) intracellular SOD plays an important role in preventing $\mathrm{H}_{2} \mathrm{O}_{2}$ damage; (c) generation of superoxide seems to occur intracellularly after exposure to $\mathrm{H}_{2} \mathrm{O}_{2}$, but independent of cellular xanthine oxidase; and $(d)$ cellular iron mediates the damage by catalyzing the production of more reactive species from superoxide and $\mathrm{H}_{2} \mathrm{O}_{2}$, the process which causes ultimate cell injury. (J. Clin. Invest. 1994. 93:331-338.) Key words: diethyldithiocarbamate $\bullet$ hydrogen peroxide $\bullet$ hydroxyl radical • iron • superoxide anion
\end{abstract}

\section{Introduction}

Gastric epithelium is constantly exposed to intraluminal generation of reactive oxygen metabolites $(\mathrm{ROM})^{1}(1-6)$. Gastric epithelial cells, together with the surface-covering mucus layer

\footnotetext{
Address correspondence to Dr. Kevin J. Ivey, 111-G, Department of Gastroenterology, Veterans Affairs Medical Center, 5901 East Seventh Street, Long Beach, CA 90822. 1993.

Received for publication 4 March 1993 and in revised form 2 August

1. Abbreviations used in this paper: CDNB, 1-chloro-2,4-dinitrobenzene; DDC, diethyldithiocarbamate; DEF, deferoxamine mesylate; EBSS, Earle's balanced salt solution; GO, glucose oxidase; GSSG, oxidized glutathione; GT, glutathione transferase; $\mathrm{O}_{2}^{\circ}$, superoxide anion radical; $\mathrm{OH}^{\bullet}$, hydroxyl radical; $\mathrm{OXY}$, oxypurinol; $\mathrm{PHE}, 1,10$-phenanthroline; ROM, reactive oxygen metabolite(s); XD, xanthine dehydrogenase; $\mathrm{XO}$, xanthine oxidase.
}

The Journal of Clinical Investigation, Inc.

Volume 93, January 1994, 331-338
$(7,8)$, may represent an initial line of defense against such luminal oxidants. However, healthy gastric epithelium appears unaffected despite the constant exposure. Thus it is highly possible that gastric epithelial cells are endowed with effective antioxidant defenses such as the glutathione redox cycle, catalase and SOD. We have previously found that the glutathione redox cycle plays a principal role in detoxifying $\mathrm{H}_{2} \mathrm{O}_{2}$ in cultured gastric mucosal cells, whereas endogenous catalase plays a minor role (9). To date, however, the possible role of intracellular SOD against such injury remains undetermined in gastric cells. Moreover, there has been disagreement as to the central importance of SOD as an intracellular antioxidant defense in other cells or microorganisms (10-14).

$\mathrm{O}_{2}^{\circ}$, the one-electron reduction product of oxygen, is generated in aerobic organisms both spontaneously and as a result of pathological events such as neutrophil activation, hyperoxia, radiation, and ischemia/reperfusion (15-21). Thus, almost all aerobes elaborate forms of SOD, an enzyme which converts $\mathrm{O}_{2}^{\circ}$ to $\mathrm{H}_{2} \mathrm{O}_{2}$. In eukaryotes, SOD is characterized by the metal found at the active center and its cellular localization. Copper, zinc-containing SOD $(\mathrm{Cu}, \mathrm{Zn}-\mathrm{SOD})$, the predominant form in mammalian cells, is located mainly in the cytosol; and the manganese-containing SOD (Mn-SOD) is primarily found in mitochondria (22). Diethyldithiocarbamate (DDC) has been shown to inhibit $\mathrm{Cu}, \mathrm{Zn}$-SOD activity by chelating copper ion, an active center of the enzyme $(23,24)$.

The present study attempted to clarify the role of intracellular SOD in maintaining the integrity of cultured gastric cells against ROM. We found that selective inhibition of intracellular SOD by DDC results in enhancement of $\mathrm{H}_{2} \mathrm{O}_{2}$ damage to cultured gastric mucosal cells. Our results also suggest that cellular iron mediates the damage by catalyzing production of more reactive species from $\mathrm{O}_{2}^{\circ}$ and $\mathrm{H}_{2} \mathrm{O}_{2}$ in these cells.

\section{Methods}

Animals and reagents. Rats, 7-10 d old, of either sex (Sprague-Dawley, Charles River Breeding Laboratories, Wilmington, MA) were used. Isolation medium consisted of Coon's modified Ham's F-12 medium (GIBCO, Grand Island, NY) containing $0.1 \%$ collagenase $(0.52 \mathrm{U} /$ $\mathrm{mg}$, Boehringer Mannheim Biochemicals, Indianapolis, IN), 0.05\% hyaluronidase (type 1-S, $295 \mathrm{U} / \mathrm{mg}$, Sigma Chemical Co., St. Louis, MO), $100 \mathrm{U} / \mathrm{ml}$ of penicillin, $100 \mu \mathrm{g} / \mathrm{ml}$ of streptomycin, and 25 $\mu \mathrm{g} / \mathrm{ml}$ of gentamicin (Sigma). Culture medium consisted of F-12 medium supplemented with heat-inactivated (at $56^{\circ} \mathrm{C}$ for $30 \mathrm{~min}$ ) $10 \%$ FBS (HyClone Laboratories, Inc., Logan, UT), 15 mM Hepes (Sigma), and the above antibiotics, $b-D(+)$ glucose, glucose oxidase (GO, 192,100 U/g solid, lot no. 19F-3775), diethyldithiocarbamate (DDC), deferoxamine mesylate (DEF), 1,10-phenanthroline (PHE), GSH, oxidized glutathione (GSSG), glutathione reductase $(200 \mathrm{U} / \mathrm{mg}$ protein), $\mathrm{NADPH}, \mathrm{H}_{2} \mathrm{O}_{2}$ (30\% solution), 1-chloro-2,4-dinitrobenzene (CDNB), dithiothreitol, SOD (from bovine liver, $2470 \mathrm{U} / \mathrm{mg}$ solid), xanthine, cytochrome $c$, sodium azide, BSA, EDTA, sulfosalicylic 
acid, 5,5'-dithiobis (2-nitrobenzoic acid), TCA, ferrous ammonium sulfate, sodium thiocyanate, calcium ionophore A23187, DMSO, sodium taurocholate, oxypurinol (OXY), and Triton X-100 were purchased from Sigma. OXY was dissolved in $1 \mathrm{~N} \mathrm{NaOH}$ as $100 \mathrm{mM}$ stock. The stock solution was diluted in culture medium to obtain the final concentration $(1 \mathrm{mM})$, and the $\mathrm{pH}$ of the solution was then brought to $\mathrm{pH} 7.4$ by addition of $1 \mathrm{~N} \mathrm{HCl}$. Calcium ionophore was dissolved in DMSO at $5 \times 10^{-3} \mathrm{M}$. Perchloric acid $\left(\mathrm{HClO}_{4}\right)$ and 2-vinylpyridine were from Aldrich Chemical Co., Milwaukee, WI. Hanks' HBSS and Earle's balanced salt solution (EBSS) supplemented with 15 $\mathrm{mM}$ Hepes were obtained from GIBCO, and adjusted to $\mathrm{pH} 7.4 .{ }^{51} \mathrm{Cr}$ (sodium chromate, $200-900 \mathrm{Ci} / \mathrm{g}$ chromium) was obtained from ICN Biochemicals, Irvine, CA. Tissue culture plates and dishes were from Costar, Cambridge, MA.

Cell culture. Primary culture of the gastric fundic mucosa from 7-10-d old rats was prepared by the method of Terano et al. (25). In brief, the intact corpus (oxyntic glandular mucosa) area was excised from the antrum and forestomach, and the full wall thickness was minced into 2- to 3- $\mathrm{mm}^{3}$ pieces. After incubation in isolation medium at $37^{\circ} \mathrm{C}$ for $60 \mathrm{~min}$ in an atmosphere of $5 \% \mathrm{CO}_{2}-95 \% \mathrm{O}_{2}$, the tissues were pipetted several times and filtered through a nylon mesh and transferred to culture medium. The filtrate was washed by centrifuging at $50 \mathrm{~g}$ for $5 \mathrm{~min}$ in HBSS. Cells in culture medium were then inoculated into culture plates or dishes. The cultures were maintained at $37^{\circ} \mathrm{C}$ with $5 \% \mathrm{CO}_{2}$ in room air in a humidified atmosphere with the media changed daily. Confluent monolayers were studied $3 \mathrm{~d}$ after seeding.

${ }^{51} \mathrm{Cr}$ release assay. Cytotoxicity was quantified by measuring ${ }^{51} \mathrm{Cr}$ release from prelabeled cells. Culture medium containing $3 \mu \mathrm{Ci} /$ well per $0.5 \mathrm{ml}{ }^{51} \mathrm{Cr}$ was added to confluent monolayers on 24-well culture plates. After overnight prelabeling, cells were washed three times with HBSS and preincubated for 60 min with either EBSS or DDC, then incubated with $1 \mathrm{ml}$ EBSS only or EBSS containing test agents at $37^{\circ} \mathrm{C}$ in $95 \%$ room air-5\% $\mathrm{CO}_{2}$. In some experiments, cells were prelabeled for $40 \mathrm{~h}$ with culture medium containing ${ }^{51} \mathrm{Cr}$ in the absence (vehicle control) or presence of OXY ( $1 \mathrm{mM})$. In GO-induced cytotoxicity assay, b-D $(+)$ glucose was substituted for a-D $(+)$ glucose in EBSS because GO uses b-D(+)glucose as substrate. $200 \mu$ l of cell-free supernatant buffer were removed at intervals for determination of specific ${ }^{51} \mathrm{Cr}$ release as follows: $(A-B / C-B) \times 100 \%$, where $A$ represents the mean test ${ }^{51} \mathrm{Cr}$ counts per minute $(\mathrm{cpm})$ released, $B$ represents the mean spontaneous ${ }^{51} \mathrm{Cr} \mathrm{cpm}$ released, and $C$ represents the mean maximum ${ }^{51} \mathrm{Cr} \mathrm{cpm}$ released. Maximum ${ }^{51} \mathrm{Cr}$ release was determined by incubation in $0.2 \%$ Triton $\mathrm{X}-100$. Spontaneous ${ }^{51} \mathrm{Cr}$ release was determined in control monolayers incubated in EBSS only and was 15-20\% of maximum ${ }^{51} \mathrm{Cr}$ release after $5 \mathrm{~h}$ of incubation. ${ }^{51} \mathrm{Cr}$ radioactivity was counted with a Gamma 7000 Counting System (Beckman Instruments, Inc., Fullerton, CA).

$\mathrm{H}_{2} \mathrm{O}_{2}$ assay. Quantitation of $\mathrm{H}_{2} \mathrm{O}_{2}$ generated by $\mathrm{GO}$ was determined by the method of Thurman et al. (26). GO was incubated for $5 \mathrm{~h}$ with $10 \mathrm{mM} \mathrm{b}-\mathrm{D}(+)$ glucose in a final volume of $1 \mathrm{ml}$ in EBSS (without phenol red). The reaction was terminated by the addition of $0.1 \mathrm{ml}$ TCA $(50 \% \mathrm{wt} / \mathrm{vol})$. The samples were centrifuged at $500 \mathrm{~g}$ for $10 \mathrm{~min}$, and $0.2 \mathrm{ml}$ of $10 \mathrm{mM}$ ferrous ammonium sulfate and $0.1 \mathrm{ml}$ of $2.5 \mathrm{M}$ sodium thiocyanate added to the supernate. Absorption of the ferrithiocyanate complex was measured at $480 \mathrm{~nm}$ and compared to a standard curve generated from dilution of concentrated $\mathrm{H}_{2} \mathrm{O}_{2}$. The $\mathrm{H}_{2} \mathrm{O}_{2}$ concentration was calculated from the absorbance at $230 \mathrm{~nm}$ assuming an extinction coefficiency of $81 \mathrm{M}^{-1} \mathrm{~cm}^{-1}$ (27).

Enzyme assay. $60-\mathrm{mm}$ dishes of control buffer- or DDC-treated cells were solubilized by incubation with $0.2 \%$ Triton $\mathrm{X}-100$ at room temperature for $1 \mathrm{~h}$, frozen at $-20^{\circ} \mathrm{C}$, and the supernatant was assayed for glutathione peroxidase, glutathione reductase and catalase (28). Glutathione peroxidase and glutathione reductase activity was determined by the oxidation of $2 \mathrm{mM}$ NADPH, monitored at $340 \mathrm{~nm}$. Catalase activity was determined by disappearance of $10 \mathrm{mM}$ hydrogen peroxide, monitored at $230 \mathrm{~nm}$. For glutathione transferase (GT) assay, cells in $60 \mathrm{~mm}$ dishes were scraped into a solution of $50 \mathrm{mM}$
Tris- $\mathrm{HCl}$ buffer containing $154 \mathrm{mM} \mathrm{KCl}, 4 \mathrm{mM}$ EDTA, and $5 \mathrm{mM}$ dithiothreitol, and sonicated. Solutions were cleared by centrifugation at $3,000 \mathrm{~g}$ for $5 \mathrm{~min}$, and an aliquot of the supernatant was assayed for GT at $340 \mathrm{~nm}$ by measuring the formation of the conjugate of GSH and CDNB (29). A unit of enzyme activity was defined as the amount of enzyme that catalyzed the formation of $1 \mu \mathrm{mol}$ of S-2,4-dinitrophenylglutathione per minute at $30^{\circ} \mathrm{C}$ using $1 \mathrm{mM}$ concentrations of GSH and CDNB. The specific activity of these enzymes was expressed as ( $\mathrm{m}) \mathrm{U} / \mathrm{mg}$ protein as determined by the method of Bradford (30). Glutathione (GSH + GSSG) in $60 \mathrm{~mm}$ dishes of cells was measured by the method of Tietze $(30,31)$. After incubation, cells were washed three times with PBS, and solubilized in $0.2 \%$ Triton X-100. An aliquot of each sample was removed for protein assay. To another aliquot, an equal volume of $2 \mathrm{M} \mathrm{HClO}_{4}, 4 \mathrm{mM}$ EDTA was added, and solutions were cleared by centrifugation at $3,000 \mathrm{~g}$ for $5 \mathrm{~min}$ to remove protein (32). An aliquot of the deproteinized, acid-soluble extract was neutralized with a solution containing $2 \mathrm{M} \mathrm{KOH}$ and $0.3 \mathrm{M} \mathrm{N}$-morpholinopropane-sulfonic acid so that $\mathrm{HClO}_{4}$ was removed by precipitation as the potassium salt (32), and the supernatant assayed for the sum of GSH and GSSG $(31,32)$. GSSG was assayed by masking GSH with $1 \%$ of 2-vinylpyridine (33). GSH and GSSG content was expressed as $\mathrm{nmol} / \mathrm{mg}$ protein. The SOD activity was determined by lyzing cells in $0.2 \%$ Triton X-100 $50 \mathrm{mM}$ potassium phosphate buffer, $0.1 \mathrm{mM}$ EDTA, pH 7.8. The lysate was centrifuged at $27,000 \mathrm{~g}$ for $30 \mathrm{~min}$ at $4^{\circ} \mathrm{C}$. The supernatant material was dialyzed overnight at $4^{\circ} \mathrm{C}$ against 100 vol $50 \mathrm{mM}$ potassium phosphate buffer with $0.1 \mathrm{mM}$ EDTA ( $\mathrm{pH}$ 7.8). The xanthine oxidase-cytochrome $c$ method was used for SOD assay (34), and sodium azide $(10 \mu \mathrm{M})$ was used to block peroxidases. The background activity was determined by adding the cell preparation to the cytochrome $c$ mixture without xanthine oxidase. No reduction of cytochrome $c$ was observed in the cell preparation. A unit of SOD activity was defined as the amount of enzyme which halved the rate of cytochrome $c$ reduction. The enzyme activity was expressed as $\mathrm{U} / \mathrm{mg}$ protein.

Statistical analysis. Data are expressed as means \pm SE. Analysis of variance and Student's $t$ test were used to assess the significance of differences; $P<0.05$ was considered significant.

\section{Results}

Cell culture. The cells reached confluency on day 3. Over $90 \%$ of the cells were identified as mucous-producing epithelial cells ( surface epithelial cells and mucous neck cells) by PAS staining and ultrastructural studies $(25,35)$. Histochemical study with succinate dehydrogenase activity identified $5 \%$ of cells as parietal cells, whereas immunohistochemical study with pepsinogen failed to reveal any chief cells (25). These cells possessed the capability to synthesize DNA as well as cyclic nucleotides $(25,36)$, to produce and secrete mucous glycoprotein $(25)$, and to generate prostaglandins (36).

Effect of pretreatment with DDC on cell lysis by enzymatically generated $\mathrm{H}_{2} \mathrm{O}_{2}$. The reaction of $\mathrm{GO}$ with the substrate b- $\mathrm{D}(+)$ glucose gives rise to the generation of $\mathrm{H}_{2} \mathrm{O}_{2}$ according to the following reaction:

$$
\text { B-D }(+) \text { glucose }+\mathrm{O}_{2}+\mathrm{H}_{2} \mathrm{O} \stackrel{\text { GO }}{\longrightarrow} \text { D-gluconic acid }+\mathrm{H}_{2} \mathrm{O}_{2}
$$

The reaction mixture of $10 \mathrm{mM} \mathrm{b}-\mathrm{D}(+)$ glucose and $20 \mathrm{mU} / \mathrm{ml}$ GO resulted in generation of $\mathrm{H}_{2} \mathrm{O}_{2}$ in amounts of $0.184 \pm 0.058$ $\mathrm{mM}$ (mean $\pm \mathrm{SE}$ of six determinations) during 5-h incubation in a cell free system. GO $(2.5-20 \mathrm{mU} / \mathrm{ml})$ caused a dose-dependent increase in specific ${ }^{51} \mathrm{Cr}$ release in the presence of $\mathrm{b}-\mathrm{D}$ glucose (Fig. 1). GO (20 mU/ml) alone did not significantly increase ${ }^{51} \mathrm{Cr}$ release; specific ${ }^{51} \mathrm{Cr}$ release by $\mathrm{GO}(20 \mathrm{mU} / \mathrm{ml})$ in the absence of glucose during 5 -h incubation was $0.4 \pm 0.3 \%$ (mean $\pm \mathrm{SE}$ of quadruplicates on three separate preparations). 


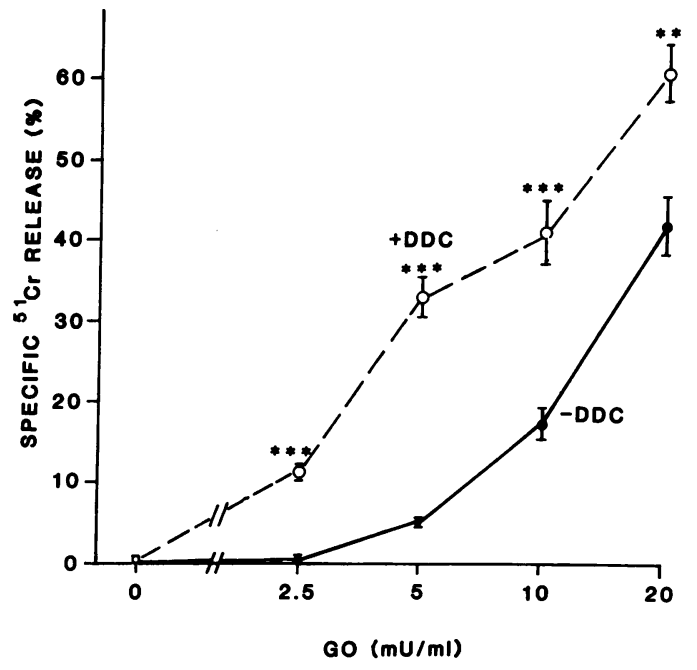

Figure 1. Effect of DDC on dose-dependent ${ }^{51} \mathrm{Cr}$ release induced by GO. Cells were labeled overnight with ${ }^{51} \mathrm{Cr}$, washed, and preincubated for $60 \mathrm{~min}$ with buffer or DDC $(10 \mu \mathrm{M})$. The cells were washed three times and then incubated with glucose $(10 \mathrm{mM})$ and $\mathrm{GO}(2.5-20$ $\mathrm{mU} / \mathrm{ml}$ ). Aliquots of supernatant buffer were removed after $5 \mathrm{~h}$ of incubation for determination of specific ${ }^{51} \mathrm{Cr}$ release. Values represent means $\pm S E$ of quadruplicates on three separate preparations. Significant differences compared with control (-DDC) values were expressed as: ${ }^{* *} P<0.01 ;{ }^{* *} P<0.001$.

GO-induced damage was inhibited specifically by extracellular catalase, and inhibition of damage was due to its enzymatic activity, since 3-amino-1,2,4-triazole (a specific inhibitor of catalase) (37) prevented the protective effect of catalase (38). Pretreatment with DDC $(10 \mu \mathrm{M}$ for $60 \mathrm{~min})$ increased susceptibility to lysis by glucose-GO, i.e., it caused a left shift of the dose-response curve for GO (Fig. 1). Pretreatment with DDC alone ( $10 \mu \mathrm{M}$ for $60 \mathrm{~min}$ ) did not significantly increase ${ }^{51} \mathrm{Cr}$ release at $5 \mathrm{~h}$ compared with control; specific ${ }^{51} \mathrm{Cr}$ release after incubation with $10 \mu \mathrm{M}$ DDC was $0.6 \pm 0.5 \%$, compared to $0.0 \pm 0.4 \%$ ( means $\pm S E$ of quadruplicates on three separate preparations) in control cultures.

Effect of pretreatment with $D D C$ on cell lysis by reagent $\mathrm{H}_{2} \mathrm{O}_{2}$. Reagent $\mathrm{H}_{2} \mathrm{O}_{2}(0.025-0.2 \mathrm{mM})$ caused a dose-dependent increase in specific ${ }^{51} \mathrm{Cr}$ release (Fig. 2). Pretreatment with DDC ( $10 \mu \mathrm{M}$ for $60 \mathrm{~min}$ ) also increased susceptibility to reagent $\mathrm{H}_{2} \mathrm{O}_{2}(0.025-0.2 \mathrm{mM}$ ) (Fig. 2).

Intracellular SOD activity in DDC-treated cells. Pretreatment with DDC $(0.1-10 \mu \mathrm{M}$ for $60 \mathrm{~min})$ caused a dose-dependent increase of glucose/GO-induced ${ }^{51} \mathrm{Cr}$ release (Fig. 3). Treatment with DDC ( $10 \mu \mathrm{M})$, while inhibiting cellular SOD activity from $5.29 \pm 0.62$ in control to $2.18 \pm 0.43 \mathrm{U} / \mathrm{mg}$ protein (means $\pm \mathrm{SE}$ of duplicates on three separate preparations), enhanced GO $(5 \mathrm{mU} / \mathrm{ml})$-induced ${ }^{51} \mathrm{Cr}$ release from $5.3 \pm 0.4 \%$ in control to $33.1 \pm 2.5 \%$ (means \pm SE of sextuplicates on three separate preparations) (Fig. 3). Both cellular SOD activity and GO-induced damage were directly correlated with the concentration of DDC. Importantly, susceptibility to lysis by $\mathrm{H}_{2} \mathrm{O}_{2}$ was inversely related to endogenous SOD activity (Fig. 3). Similarly, pretreatment with DDC caused a dose-dependent increase in reagent $\mathrm{H}_{2} \mathrm{O}_{2}$-induced ${ }^{51} \mathrm{Cr}$ release (Fig. 4). DDC ( 10 $\mu \mathrm{M})$ enhanced reagent $\mathrm{H}_{2} \mathrm{O}_{2}(0.05 \mathrm{mM})$-induced ${ }^{51} \mathrm{Cr}$ release from $8.8 \pm 1.2 \%$ in control to $30.8 \pm 3.5 \%$ (means $\pm \mathrm{SE}$ of sextuplicates on 3 separate preparations) (Fig. 4).

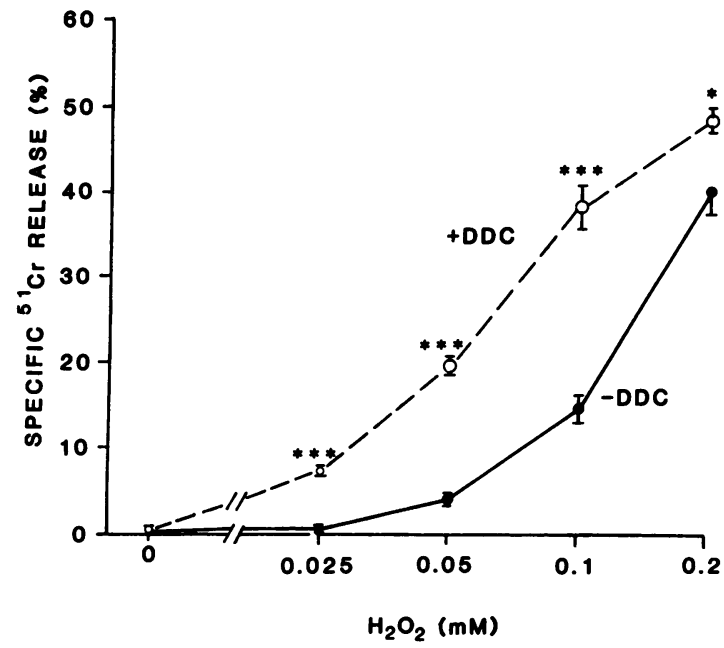

Figure 2. Effect of DDC on dose-dependent ${ }^{51} \mathrm{Cr}$ release induced by reagent $\mathrm{H}_{2} \mathrm{O}_{2}$. Cells were labeled overnight with ${ }^{51} \mathrm{Cr}$, washed, and preincubated for $60 \mathrm{~min}$ with buffer or DDC $(10 \mu \mathrm{M})$. The cells were washed three times and then incubated with reagent $\mathrm{H}_{2} \mathrm{O}_{2}(0.025-0.2$ $\mathrm{mM}$ ). Aliquots of supernatant buffer were removed after $5 \mathrm{~h}$ incubation for determination of specific ${ }^{51} \mathrm{Cr}$ release. Values represent means $\pm \mathrm{SE}$ of quadruplicates on three separate preparations. Significant differences compared with control $(-D D C)$ values were expressed as: ${ }^{*} P<0.05 ;{ }^{* *} P<0.001$.

Specificity of DDC for $\mathrm{H}_{2} \mathrm{O}_{2}$-mediated injury. Susceptibility to lysis by distilled water, calcium ionophore $(5 \mu \mathrm{M})$, and taurocholate $(5 \mathrm{mM})$ was not affected by pretreatment with DDC

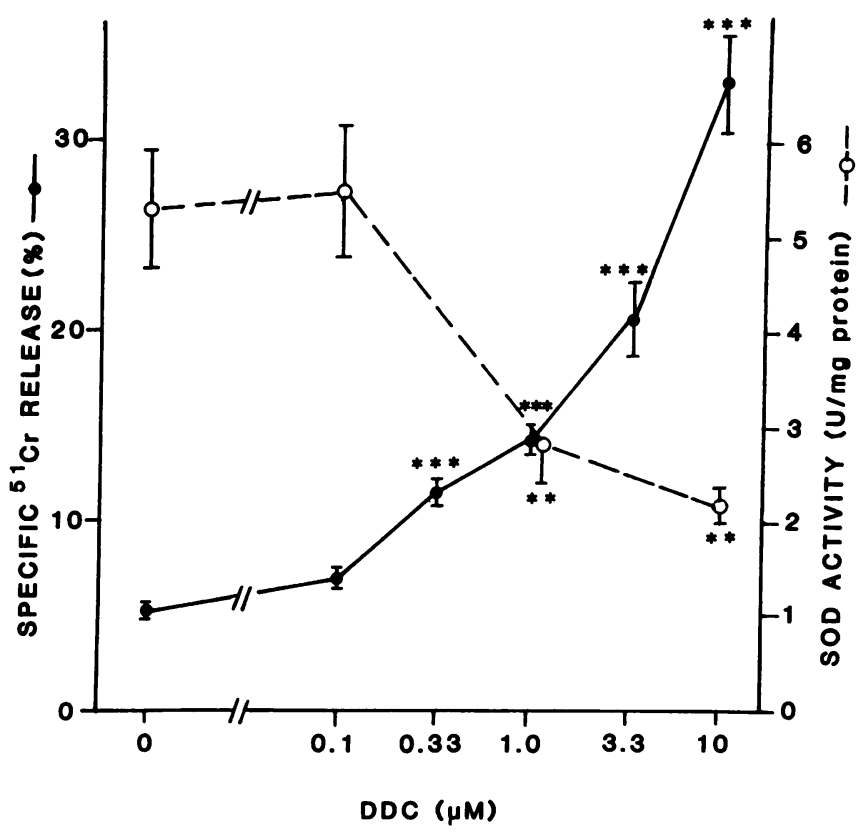

Figure 3. Effect of DDC concentration on SOD activity and GO-induced ${ }^{51} \mathrm{Cr}$ release. SOD activity and $\mathrm{GO}$-induced ${ }^{51} \mathrm{Cr}$ release were determined in gastric cells after a 60-min incubation with increasing concentrations of DDC $(0.1-10 \mu \mathrm{M})$. GO-induced ${ }^{51} \mathrm{Cr}$ release was determined after incubation with glucose $(10 \mathrm{mM})$ and $\mathrm{GO}(5 \mathrm{mU} /$ $\mathrm{ml}$ ) for $5 \mathrm{~h}$. Values for SOD activity and for ${ }^{51} \mathrm{Cr}$ release represent means $\pm \mathrm{SE}$ of duplicates and sextuplicates on three separate preparations, respectively. Significant differences compared with control (DDC 0 ) values were expressed as: ${ }^{* *} P<0.01 ;{ }^{* * *} P<0.001$. 




Figure 4. Effect of DDC concentration on reagent $\mathrm{H}_{2} \mathrm{O}_{2}$-induced ${ }^{51} \mathrm{Cr}$ release. Reagent $\mathrm{H}_{2} \mathrm{O}_{2}$-induced ${ }^{51} \mathrm{Cr}$ release was determined after a 60-min incubation with increasing concentrations of DDC (0.1-10 $\mu \mathrm{M})$. Specific ${ }^{51} \mathrm{Cr}$ release was determined after incubation with reagent $\mathrm{H}_{2} \mathrm{O}_{2}(0.05 \mathrm{mM})$ for $5 \mathrm{~h}$. Values for ${ }^{51} \mathrm{Cr}$ release represent means $\pm \mathrm{SE}$ of sextuplicates on three separate preparations. Significant differences compared with control (DDC 0 ) values were expressed as: ${ }^{* *} P<0.01{ }^{* * *} P<0.001$.

( $10 \mu \mathrm{M}$ for $60 \mathrm{~min}$ ), despite DDC potentiation of ${ }^{51} \mathrm{Cr}$ release by reagent $\mathrm{H}_{2} \mathrm{O}_{2}(0.1 \mathrm{mM})$ in the same preparations (Table I).

Effect of iron chelation on DDC-induced enhancement of $\mathrm{H}_{2} \mathrm{O}_{2}$ injury. We have previously found that chelation of cellular iron inhibits $\mathrm{H}_{2} \mathrm{O}_{2}$-induced injury to these cells $(38,39)$. To further confirm the role of intracellular $\mathrm{SOD}$ in $\mathrm{H}_{2} \mathrm{O}_{2}$-induced injury, and to assess the possible importance of iron in mediating injury in cells with inhibited SOD, the effects of iron chelators, i.e., DEF (a chelator of $\mathrm{Fe}^{3+}$ ) (40-42) and PHE (a chelator of divalent $\left.\mathrm{Fe}^{2+}\right)(43,44)$, were examined. In experiments

Table I. Effect of DDC on ${ }^{51} \mathrm{Cr}$ Release Induced by Nonoxidant Agents

\begin{tabular}{llc}
\hline & \multicolumn{2}{c}{ Percentage of specific ${ }^{\text {si }} \mathrm{Cr}$ release } \\
\cline { 2 - 3 } Addition & -DDC & +DDC \\
\hline Distilled water & $19.5 \pm 0.9$ & $18.9 \pm 1.5$ \\
A23187 & $20.9 \pm 1.4$ & $20.4 \pm 1.5$ \\
Taurocholate & $11.2 \pm 0.8$ & $11.8 \pm 0.7$ \\
$\mathrm{H}_{2} \mathrm{O}_{2}$ & $14.6 \pm 1.6$ & $38.4 \pm 2.5^{*}$ \\
\hline
\end{tabular}

${ }^{51} \mathrm{Cr}$-labeled cells were preincubated for $60 \mathrm{~min}$ with buffer or DDC $(10 \mu \mathrm{M})$. The cells were washed three times and then incubated with distilled water for $30 \mathrm{~min}, \mathrm{~A} 23187(5 \mu \mathrm{M})$, taurocholate $(5 \mathrm{mM})$, or $\mathrm{H}_{2} \mathrm{O}_{2}(0.1 \mathrm{mM})$ for $5 \mathrm{~h}$. Aliquots of supernatant buffer were removed for determination of specific ${ }^{51} \mathrm{Cr}$ release. Values represent means $\pm \mathrm{SE}$ of quadruplicates on three separate preparations. Significant differences compared with control values were expressed as: ${ }^{*} P<0.001$. with DEF, cells were preincubated for $60 \mathrm{~min}$ with or without $\operatorname{DEF}(20 \mathrm{mM}$ ), and then further incubated for $60 \mathrm{~min}$ with or without DDC $(0.1-10 \mu \mathrm{M})$ before exposure to $\mathrm{GO}(5 \mathrm{mU} / \mathrm{ml})$ (Fig. 5). In experiments with PHE, cells were preincubated with or without DDC $(0.1-10 \mu \mathrm{M})$, and then incubated with reagent $\mathrm{H}_{2} \mathrm{O}_{2}(0.05 \mathrm{mM})$ in the presence or absence of PHE $(10 \mu \mathrm{M})$ (Fig. 6). Strikingly, both DEF (20 mM) and PHE ( 10 $\mu \mathrm{M})$ significantly and nearly completely prevented DDC-induced enhancement of susceptibility to lysis by $\mathrm{H}_{2} \mathrm{O}_{2}$ (Figs. 5 and 6).

Effect of DDC on antioxidant defenses. We determined the effects of DDC on GSH and GSSG content, glutathione peroxidase, glutathione reductase, GT, and catalase activity. As summarized in Table II, inhibition of cellular SOD activity with DDC ( $10 \mu \mathrm{M}$ for $60 \mathrm{~min}$ ) was not associated with significant alteration of the glutathione redox cycle, GT or catalase. These results excluded the possibility that DDC potentiated $\mathrm{H}_{2} \mathrm{O}_{2}$-induced damage by impairing cellular antioxidant defenses (9) other than SOD.

Effect of $O X Y$ on DDC-induced sensitization of GO-induced injury. To determine whether cellular XO-derived $\mathrm{O}_{2}^{\bullet}$ is involved in mediating $\mathrm{H}_{2} \mathrm{O}_{2}$-induced damage to cells with inhibited SOD, we examined the effect of OXY, an inhibitor of XO $(38,45,46)$, on DDC-induced sensitization of gastric cell to GO damage. Cells were labeled with ${ }^{51} \mathrm{Cr}$ for $40 \mathrm{~h}$ in the absence or presence of OXY ( $1 \mathrm{mM})$, and preincubated for 60 min with buffer (control) or DDC $(10 \mu \mathrm{M})$ before cytotoxicity assay by glucose/GO $(7.5 \mathrm{mU} / \mathrm{ml})$. Prelabeling with OXY (1 $\mathrm{mM}$ ) did not influence the incorporation of ${ }^{51} \mathrm{Cr}$ applied into cells (data not shown). As shown in Table III, preincubation with OXY neither prevented lysis by GO nor diminished enhanced susceptibility to GO by DDC.

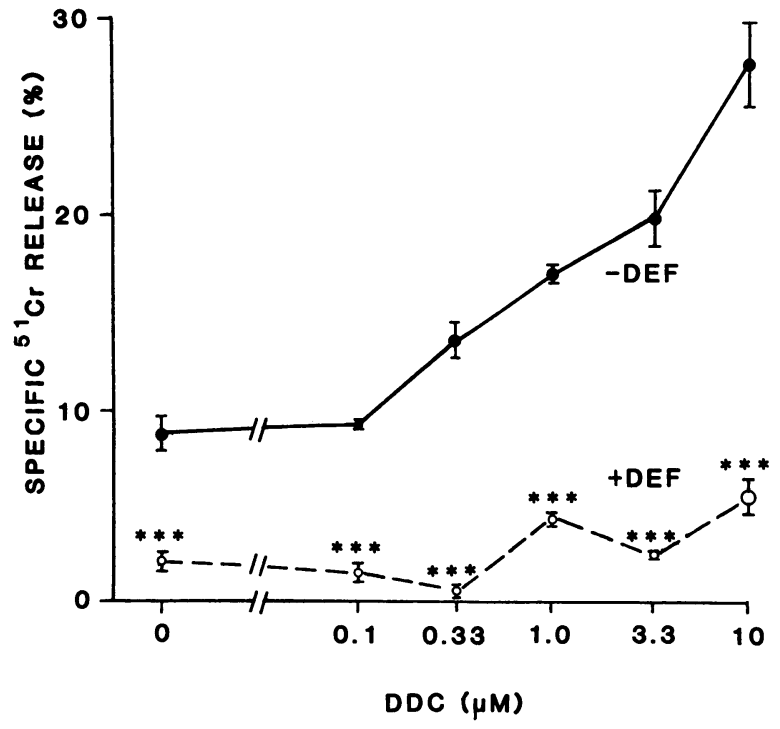

Figure 5. Effect of DEF on DDC-induced sensitization of lysis by GO. ${ }^{51} \mathrm{Cr}$-labeled cells were incubated with buffer or $20 \mathrm{mM}$ DEF for 60 $\mathrm{min}$, washed, and then further incubated for $60 \mathrm{~min}$ with buffer or DDC $(0.1-10 \mu \mathrm{M})$ before exposure to glucose $(10 \mathrm{mM}) / \mathrm{GO}(5$ $\mathrm{mU} / \mathrm{ml}$ ). Aliquots of supernatant buffer were removed after $5 \mathrm{~h}$ incubation for determination of specific ${ }^{51} \mathrm{Cr}$ release. Values represent means $\pm S E$ of quadruplicates on three separate preparations. Significant differences compared with control ( $-\mathrm{DEF})$ values were expressed as: ${ }^{* * *} P<0.001$. 


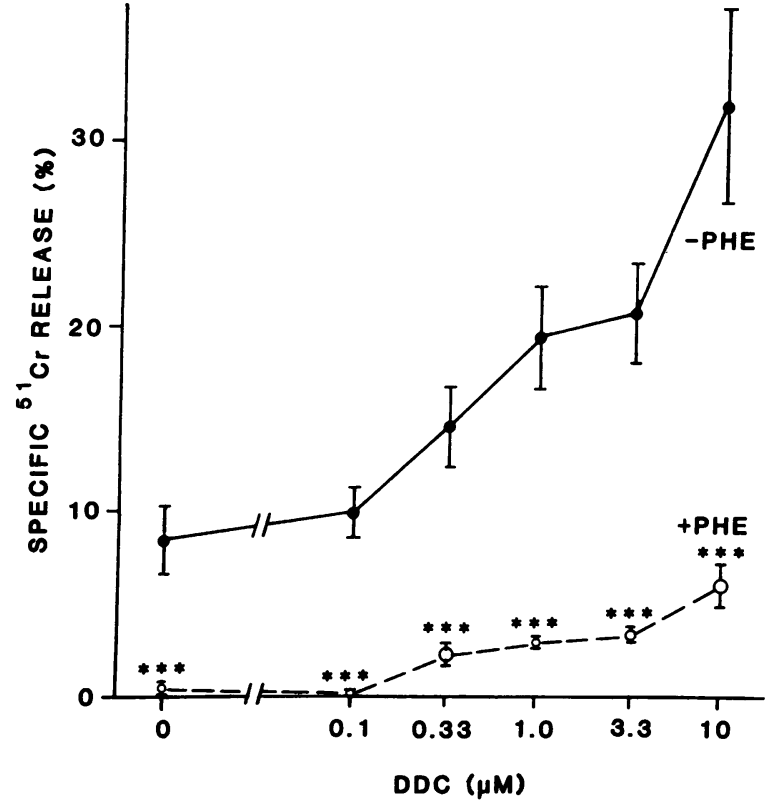

Figure 6. Effect of PHE on DDC-induced sensitization of lysis by $\mathrm{H}_{2} \mathrm{O}_{2} \cdot{ }^{51} \mathrm{Cr}$-labeled cells were preincubated for $60 \mathrm{~min}$ with buffer or DDC $(0.1-10 \mu \mathrm{M})$. The cells were washed three times and then incubated with reagent $\mathrm{H}_{2} \mathrm{O}_{2}(0.05 \mathrm{mM})$ in the presence or absence of PHE $(10 \mu \mathrm{M})$. Aliquots of supernatant buffer were removed after 5 $h$ incubation for determination of specific ${ }^{51} \mathrm{Cr}$ release. Values represent means $\pm \mathrm{SE}$ of quadruplicates on three separate preparations. Significant differences compared with control (-PHE) values were expressed as: ${ }^{* * *} P<0.001$.

\section{Discussion}

Although SOD is found intracellularly in almost all aerobes, its importance as an antioxidant is by no means certain. It has been reported that cultured endothelial cells with increased SOD activity (as much as 17 -fold) after incubation with native SOD were more resistant to killing by $\mathrm{H}_{2} \mathrm{O}_{2}$ and activated neutrophils (10). In contrast, incubation of endothelial cells with polyethylene glycol conjugated SOD failed to protect cells from $\mathrm{XO}$-induced ${ }^{51} \mathrm{Cr}$ release, although the manipulation increased cellular SOD by fourfold (11). Microinjection of SOD into endothelial cells was also shown not to be protective against hyperoxia-induced toxicity (12). In microorganisms, on the contrary, SOD-rich $E$. coli was less resistant to paraquat (an intracellular $\mathrm{O}_{2}^{\circ}$ generator ), hyperoxia, or r-radiation $(13,14)$. Thus, it is possible that the protective role of cellular SOD against oxidant may depend on cell types. Alternatively, the balance of antioxidant defense functions may be more important than simple adjustments of individual parts of the system (14).

Therefore, the present study addressed the role of intracellular SOD in protection of cultured gastric cells against extracellular oxidants by inhibiting the enzyme to subnormal levels with DDC. DDC has been shown to inhibit $\mathrm{Cu}, \mathrm{Zn}-\mathrm{SOD}$ activity by chelating copper ion, an active center of the enzyme both in vivo and in vitro $(23,24)$. However, since there are many copper containing enzymes which may be affected by DDC, and since nonspecific effects of this agent other than through chelating copper ion have been described in other cell types (47-49), the effect of DDC on intracellular SOD activity as well as on oxidant-induced injury requires careful interpretation.

In cultured gastric mucosal cells, we found that treatment with DDC ( $10 \mu \mathrm{M}$ for $60 \mathrm{~min}$ ) significantly sensitized cells against extracellular $\mathrm{H}_{2} \mathrm{O}_{2}$, i.e., it caused a left shift of the dose response curve for enzymatically generated (continuous) and reagent (bolus) $\mathrm{H}_{2} \mathrm{O}_{2}$ (Figs. 1 and 2). Moreover, susceptibility to lysis by $\mathrm{H}_{2} \mathrm{O}_{2}$ was inversely related to inhibition of SOD activity, when cells were treated with increasing concentrations of DDC (1-10 $\mu \mathrm{M})$ (Figs. 3 and 4). With regard to specificity of the effect of DDC on $\mathrm{H}_{2} \mathrm{O}_{2}$-induced gastric cell damage, susceptibility to lysis by nonoxidant toxic agents such as distilled water, calcium ionophore, or taurocholate was not affected by DDC, despite DDC potentiation of ${ }^{51} \mathrm{Cr}$ release by $\mathrm{H}_{2} \mathrm{O}_{2}$ in the same preparations (Table I).

The gastric mucosal cells used in the present study are endowed with the glutathione redox cycle and endogenous catalase against $\mathrm{H}_{2} \mathrm{O}_{2}(9)$, and glutathione transferase. As shown in Table II, inhibition of cellular SOD by DDC was not associated with significant alteration of the content or activity of these antioxidants, supporting the interpretation that potentiation of $\mathrm{H}_{2} \mathrm{O}_{2}$ damage by DDC was due to the inhibition of cellular SOD activity.

The use of DDC as an inhibitor of $\mathrm{Cu}, \mathrm{Zn}$-SOD has been criticized $(47,48)$. In erythrocytes with oxyhemoglobin, DDC may undergo a cyclic redox reaction to produce GSSG and hydrogen peroxide (47). This could increase cell death by a non-SOD inhibition pathway. We specifically tested whether GSSG was increased by DDC treatment in gastric cells, and found that the level of GSSG and the ratio of GSH to GSSG (GSH/GSSG) were not altered by DDC (Table II), consistent with results found in cultured cerebral astrocytes (49). Thus, it is unlikely that DDC undergoes such a cyclic redox reaction in gastric cells without oxyhemoglobin, which is in agreement with the findings in erythrocytes (47). The use of nonthiol copper chelators other than DDC was considered. However,

Table II. Effect of DDC on Antioxidant Defense

\begin{tabular}{|c|c|c|c|c|c|c|}
\hline Addition & GSH +2 GSSG & 2GSSG & GP & GR & GT & CAT \\
\hline & \multicolumn{2}{|c|}{ nmol/mg protein } & \multicolumn{3}{|c|}{$m U / m g$ protein } & $U / m g$ \\
\hline Control & $15.43 \pm 0.09$ & $0.33 \pm 0.04$ & $51.4 \pm 2.1$ & $38.8 \pm 2.3$ & $93.9 \pm 3.9$ & $3.33 \pm 0.25$ \\
\hline DDC & $15.40 \pm 0.45$ & $0.32 \pm 0.06$ & $54.5 \pm 2.1$ & $39.5 \pm 3.5$ & $92.0 \pm 5.8$ & $3.58 \pm 0.26$ \\
\hline
\end{tabular}

Cells were incubated for 60 min with buffer (control) or DDC (10 $\mu \mathrm{M})$, and GSH and GSSG content and activity of glutathione peroxidase (GP), glutathione reductase (GR), glutathione transferase (GT), and catalase (CAT) were determined as described in the text. Values represent means \pm SE of duplicates on 3 separate preparations. 
Table III. Effect of $O X Y$ on DDC-induced Sensitization of GO-induced Injury

\begin{tabular}{lll}
\hline & \multicolumn{2}{c}{$\begin{array}{c}\text { Percentage of } \\
\text { specific }\end{array}$} \\
\cline { 2 - 3 } Incubation & $-\mathrm{DDC}$ & $+\mathrm{DDC}$ \\
\hline Control & $11.9 \pm 0.7$ & $32.3 \pm 1.0$ \\
OXY $1.0 \mathrm{mM}$ & $12.0 \pm 0.7$ & $33.8 \pm 1.2$
\end{tabular}

Cells were labeled with ${ }^{51} \mathrm{Cr}$ for $40 \mathrm{~h}$ in the absence (vehicle control) or presence of OXY $(1 \mathrm{mM})$, washed, and preincubated for $60 \mathrm{~min}$ with control buffer $(-\mathrm{DDC})$ or DDC $(10 \mu \mathrm{M})$. The cells were washed three times and then incubated with glucose $(10 \mathrm{mM}) / \mathrm{GO}(7.5 \mathrm{mU} /$ $\mathrm{ml})$. Aliquots of supernatant buffer were removed after $5 \mathrm{~h}$ incubation for determination of specific ${ }^{51} \mathrm{Cr}$ release. Values represent means $\pm \mathrm{SE}$ of quadruplicates on three separate preparations.

other copper chelating agents have been shown to be less effective in inhibiting SOD activity, or not to inhibit SOD activity because of inability to remove copper from SOD (47). Therefore, DDC seems the most relevant copper chelator to examine the role of SOD in gastric cells.

Finally, the observation that chelation of cellular iron diminished DDC-enhanced sensitization of these cells against $\mathrm{H}_{2} \mathrm{O}_{2}$ provided other evidence that cellular SOD is specifically involved in protecting gastric cells against $\mathrm{H}_{2} \mathrm{O}_{2}$-induced lysis. Iron is stored in cells as low molecular weight iron chelates, heme-associated iron, and ferritin bound iron mostly in the form of ferric ion $\left(\mathrm{Fe}^{3+}\right)(41,50) . \mathrm{Fe}^{3+}$ bound to ligands (L) may need to be reduced to $\mathrm{Fe}^{2+}$ so that $\mathrm{H}_{2} \mathrm{O}_{2}$ can react with $\mathrm{Fe}^{2+}$ to form a peroxo complex, yielding $\mathrm{OH}^{\bullet}$ and/or being oxidized to higher oxidation states of iron as follows (51-54):

$$
\begin{gathered}
\mathrm{L}-\mathrm{Fe}^{3+} \stackrel{\text { reductant }}{\longrightarrow} \mathrm{L}-\mathrm{Fe}^{2+} \\
\mathrm{L}-\mathrm{Fe}^{2+}+\mathrm{H}_{2} \mathrm{O}_{2} \rightarrow \mathrm{L}^{2+} \mathrm{Fe}^{2+}-\mathrm{H}_{2} \mathrm{O}_{2} \\
\mathrm{~L}_{-} \mathrm{Fe}^{2+}-\mathrm{H}_{2} \mathrm{O}_{2} \rightarrow \mathrm{L}^{2+} \mathrm{Fe}^{3+}+\mathrm{OH}^{-}+\mathrm{OH}^{\circ} \\
\mathrm{L}-\mathrm{Fe}^{2+}-\mathrm{H}_{2} \mathrm{O}_{2} \rightarrow \mathrm{L}^{2} \mathrm{Fe}^{4+}+2 \mathrm{OH}^{-}
\end{gathered}
$$

$\mathrm{O}_{2}^{\circ}$ or other cellular reductants (e.g., ascorbate, thiols, etc.) ( 52 , 55-58) are candidates to react with $\mathrm{L}-\mathrm{Fe}^{3+}$ to form $\mathrm{L}-\mathrm{Fe}^{2+}$. We have previously found that DEF and PHE protect these cells against $\mathrm{H}_{2} \mathrm{O}_{2}$ by chelating cellular iron without affecting endogenous antioxidants, whereas chelation of iron was unable to protect against lysis by nonoxidant toxic agents (38). The current study demonstrated that, in cells where endogenous SOD was inhibited with DDC $(0.1-10 \mu \mathrm{M})$, both iron chelators significantly and nearly completely prevented the DDCinduced enhancement of $\mathrm{H}_{2} \mathrm{O}_{2}$ damage (Figs. 5 and 6). These results suggest that DDC-induced sensitization against $\mathrm{H}_{2} \mathrm{O}_{2}$ is exclusively due to ROM-involved processes, and that the cellular iron is essential to mediate ROM-induced injury even in cells with inhibited SOD. Furthermore, these results also suggest that these two precursors, $\mathrm{O}_{2}^{\circ}$ and $\mathrm{H}_{2} \mathrm{O}_{2}$ alone without iron, are less toxic to gastric cells.

Thus among the candidates to reduce cellular $\mathrm{Fe}^{3+}$ to $\mathrm{Fe}^{2+}$ $(52,55-58), \mathrm{O}_{2}^{\circ}$ seems most likely the one to react with $\mathrm{Fe}^{3+}$ to liberate $\mathrm{Fe}^{2+}$. Thus we focused on the source of this $\mathrm{O}_{2}^{\circ}$ genera- tion after exposure to $\mathrm{H}_{2} \mathrm{O}_{2}$. Exposure to $\mathrm{H}_{2} \mathrm{O}_{2}$ has been shown to cause a rapid and profound fall in cellular ATP levels with enhanced accumulation of its degradation products such as hypoxanthine in in vitro cells $(59,60)$; hypoxanthine can be a substrate of cellular XO to generate $\mathrm{O}_{2}^{\circ}(61,62)$. Unexpectedly, however, $40 \mathrm{~h}$ of treatment with $1 \mathrm{mM} \mathrm{OXY,} \mathrm{which} \mathrm{inhibits} \mathrm{O}_{2}^{\circ}$ generation from XO $(45,46)$, neither prevented lysis by $\mathrm{H}_{2} \mathrm{O}_{2}$ nor diminished increased susceptibility to $\mathrm{H}_{2} \mathrm{O}_{2}$ by DDC ( Table III). Thus it seems unlikely that XO-derived $\mathrm{O}_{2}^{\bullet}$ is involved in mediating $\mathrm{H}_{2} \mathrm{O}_{2}$-induced damage.

With respect to the source of $\mathrm{O}_{2}^{\bullet}$, one possible explanation was suggested by Gutteridge et al. (63), who recently demonstrated that $\mathrm{H}_{2} \mathrm{O}_{2}$ produces hydroperoxyl radical acting on EDTA- $\mathrm{Fe}^{3+}$ through the formation of an intermediate iron-oxygen complex, which may in turn produce $\mathrm{O}_{2}^{\bullet}$ as follows:

$$
\begin{aligned}
\mathrm{Fe}^{3+} \text {-EDTA }+\mathrm{H}_{2} \mathrm{O}_{2} & \rightarrow \mathrm{Fe}^{3+} \text {-OOH } \\
\mathrm{Fe}^{3+}-\mathrm{OOH}^{-} \text {-EDTA }+\mathrm{H}_{2} \mathrm{O}_{2} & \rightarrow \mathrm{FeO}^{2+} \text {-EDTA }+\mathrm{HO}_{2}^{\bullet}+\mathrm{H}_{2} \mathrm{O} \\
\mathrm{FeO}^{2+} \text {-EDTA }+\mathrm{H}_{2} \mathrm{O}_{2} & \rightarrow \mathrm{Fe}^{3+} \text {-EDTA }+\mathrm{HO}_{2}^{\bullet}+\mathrm{OH}^{-} \\
\mathrm{HO}_{2}^{\bullet} & \rightarrow \mathrm{H}^{+}+\mathrm{O}_{2}^{\bullet}
\end{aligned}
$$

Thus it is possible that $\mathrm{H}_{2} \mathrm{O}_{2}$ initiates this chain of reaction by interacting with $\mathrm{Fe}^{3+}$ bound to biomolecules (ATP or ADP) instead of EDTA (41). Alternatively, $\mathrm{O}_{2}^{\circ}$ spontaneously derived from mitochondria, chloroplast, or endoplasmic reticulum may act as a reductant of iron (58). Once $\mathrm{O}_{2}^{\circ}$ would be generated following exposure to excess $\mathrm{H}_{2} \mathrm{O}_{2}$, it would result in the formation of a peroxo complex which yields $\mathrm{OH}^{\bullet}$ and/or is oxidized to higher oxidation states of iron by reducing $\mathrm{Fe}^{3+}$ (51-54).

In contrast to the protective role of intracellular SOD, we have previously demonstrated that extracellularly supplied SOD does not protect these cells from cytolysis induced by either XO or GO $(38,64)$. Thus, it is obvious that extracellular $\mathrm{O}_{2}^{\bullet}$ is not involved in mediating $\mathrm{H}_{2} \mathrm{O}_{2}$ damage in gastric cells, consistent with earlier finding that $\mathrm{O}_{2}^{\circ}$ is unlikely to penetrate cell membranes because of its negative charge and high reactivity (65). Although extracellularly supplied SOD has been shown to prevent damage induced by $\mathrm{GO}$ in cultured hepatocytes (66), the discrepancy with respect to the role of extracellular SOD may depend on whether the cell type can take up the enzyme (67). Thus it is highly possible that gastric cells cannot take up the enzyme in its native form in a short incubation in vitro, in agreement with earlier observations in endothelial cells that SOD needs to be entrapped by liposomes or polyethylene glycol to get access to the interior of cells $(11,68)$.

In summary, we have demonstrated that $(a)$ inhibition of cellular SOD activity with DDC dose dependently potentiated damage induced by $\mathrm{H}_{2} \mathrm{O}_{2}$, but not by non-oxidant toxic agents; (b) potentiation of $\mathrm{H}_{2} \mathrm{O}_{2}$ damage by DDC correlated with the degree of inhibition of the enzyme activity; $(c)$ treatment with DDC was not associated with alteration of other antioxidant defenses such as the glutathione redox cycle, glutathione transferase, or catalase; $(d)$ enhancement of $\mathrm{H}_{2} \mathrm{O}_{2}$-mediated damage by DDC was significantly prevented by chelation of cellular iron with DEF or PHE; however, $(e)$ inhibition of cellular XO by oxypurinol neither prevented lysis by $\mathrm{H}_{2} \mathrm{O}_{2}$ nor diminished DDC-induced sensitization to $\mathrm{H}_{2} \mathrm{O}_{2}$.

Based on these observations, together with our previous findings $(9,38,39,64)$, we postulate the following mechanisms of $\mathrm{H}_{2} \mathrm{O}_{2}$-induced damage to gastric cells and enhance- 


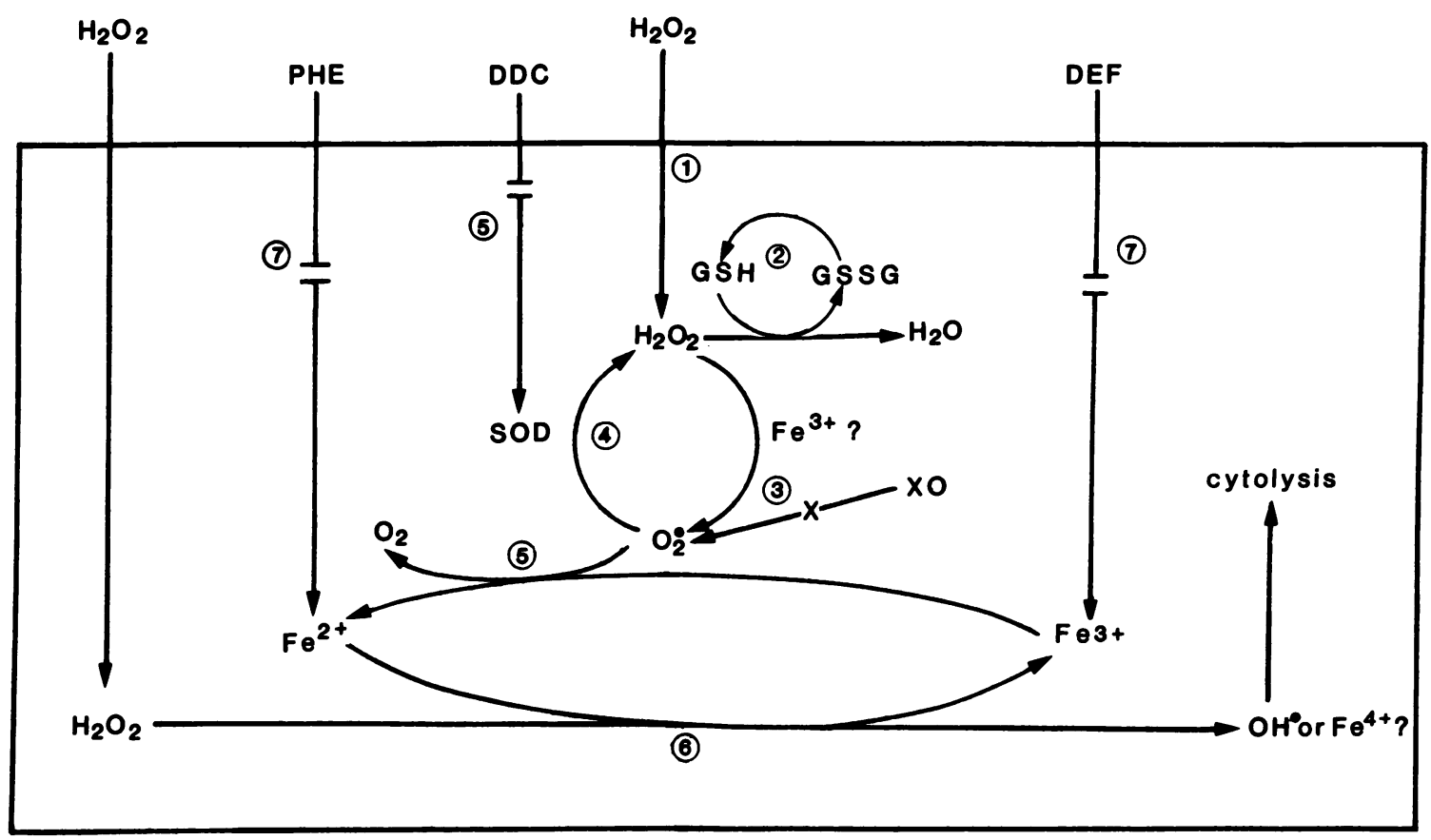

Figure 7. Postulated mechanisms of augmentation of $\mathrm{H}_{2} \mathrm{O}_{2}$-induced injury by inhibition of cellular SOD. See details in the final part of the Discussion.

ment of damage by inhibition of intracellular SOD (Fig. 7): ( 1 ) extracellular $\mathrm{H}_{2} \mathrm{O}_{2}$ penetrates cell membranes because it is electroneutral (65); (2) $\mathrm{H}_{2} \mathrm{O}_{2}$, which enters the interior of cells, is detoxified principally by the glutathione redox cycle (9): (3) excess $\mathrm{H}_{2} \mathrm{O}_{2}$ causes $\mathrm{O}_{2}^{\circ}$ generation intracellularly (possibly through reacting with $\mathrm{Fe}^{3+}$ ), which process is independent of the cellular XO/XD system; (4) cellular SOD prevents reduction of $\mathrm{Fe}^{3+}$ to $\mathrm{Fe}^{2+}$ by dismutating $\mathrm{O}_{2}^{\circ}$ into $\mathrm{H}_{2} \mathrm{O}_{2} ;(5)$ excess $\mathrm{H}_{2} \mathrm{O}_{2}$ may also inhibit SOD activity simultaneously (69). When SOD is disrupted by DDC or overwhelmed, accumulated $\mathrm{O}_{2}^{\bullet}$ initiates reduction of stored $\mathrm{Fe}^{3+}$ to $\mathrm{Fe}^{2+} ;(6)$ reduced $\mathrm{Fe}^{2+}$ reacts with $\mathrm{H}_{2} \mathrm{O}_{2}$ to form more toxic species, which ultimately causes cell damage; and (7) DEF and PHE protect cells by chelating stored iron $\left(\mathrm{Fe}^{3+}\right)$ and reduced iron $\left(\mathrm{Fe}^{2+}\right)$, respectively, presumably through inhibition of generation of such species.

Since the gastric epithelium is constantly exposed to intraluminal oxidants, we may speculate that cellular SOD may also be critical in preventing gastric epithelial injury in vivo.

\section{Acknowledgments}

This work was supported by the Medical Research Service of the Veterans Affairs, and by a grant-in-aid for scientific research from the Ministry of Education, Science and Culture of Japan.

\section{References}

1. Nayfield, S. G., T. H. Kent, and N. F. Rodman. 1976. Gastrointestinal effects of acute ferrous sulfate poisoning in rats. Arch. Pathol. Lab. Med. 100:325-328.

2. Thomas, E. L., K. P. Bates, and M. M. Jefferson. 1980. Hypothiocyanate ion: detection of the antimicrobial agent in human saliva. J. Dent. Res. 59:14661472.

3. Carlsson, J., Y. Iwami, and T. Yamada. 1983. Hydrogen peroxide excretion by oral streptococci and effect of lactoperoxidase-thiocyanate-hydrogen peroxide. Infect. Immun. 40:70-80.
4. Cross, C. E., B. Halliwell, and A. Allen. 1984. Antioxidant protection: a function of tracheobronchial and gastrointestinal mucus. Lancet. 1:1328-1330.

5. Nakayama, T., M. Kodama, and C. Nagata. 1984. Generation of hydrogen peroxide and superoxide anion radical from cigarette smoke. Jpn. J. Cancer Res. 75:95-98.

6. Grisham, M. B., L. A. Hernandez, and D. N. Granger. 1986. Xanthine oxidase and neutrophil infiltration in intestinal ischemia. Am. J. Physiol. 251:G567-574.

7. Grisham, M. B., C. Von Ritter, B. F. Smith, J. T. LaMont, and D. N. Granger. 1987. Interaction between oxygen radicals and gastric mucin. Am. J. Physiol. 253:G93-96.

8. Gong, D., B. Turner, K. R. Bhaskar, and J. T. LaMont. 1990. Lipid binding to gastric mucin: protective effect against oxygen radicals. Am. J. Physiol. 259:G681-686.

9. Hiraishi, H., A. Terano, S. Ota, H. Mutoh, T. Sugimoto, M. Razandi, and K. J. Ivey. 1991. Antioxidant defenses of cultured gastric cells against oxygen metabolites: role of GSH redox cycle and endogenous catalase. Am. J. Physiol. 261:G921-G928.

10. Markey, B. A., S. H. Phan, J. Varani, U. S. Ryan, and P. A. Ward. 1990 Inhibition of cytotoxicity by intracellular superoxide dismutase supplementation. Free Radicals Biol. Med. 9:307-314.

11. Beckman, J. S., R. L. Minor, Jr., C. W. White, J. E. Repine, G. M. Rosen, and B. A. Freeman. 1988. Superoxide dismutase and catalase conjugated to polyethylene glycol increases endothelial enzyme activity and oxidant resistance. $J$. Biol. Chem. 263:6884-6892.

12. Michiels, C., O. Toussaint, and J. Remacle. 1990. Comparative study of oxygen toxicity in human fibroblasts and endothelial cells. J. Cell Physiol. 144:295-302.

13. Scott, M. D., S. R. Meshnick, and J. W. Eaton. 1987. Superoxide dismutase-rich bacteria: paradoxical increase in oxidant toxicity. J. Biol. Chem. 262:3640-3645

14. Scott, M. D., S. R. Meshnick, and J. W. Eaton. 1989. Superoxide dismutase amplifies organismal sensitivity to ionizing radiation. J. Biol. Chem. 264:2498-2501.

15. Freeman, B. A., and J. D. Crapo. 1982. Biology of disease. Free radicals and tissue injury. Lab. Invest. 26:412-426, 1982.

16. Taylor, A. E., and D. J. Martin. 1983. Oxygen radicals and the microcirculation. Physiologist. 26:152-155.

17. Granger, D. N., G. Rutili, and J. M. McCord. 1981. Superoxide radicals in feline intestinal ischemia. Gastroenterology. 81:22-29.

18. Korthuis, R. J., and D. N. Granger. 1986. Ischemia-reperfusion injury: role of oxygen-derived free radicals. In Physiology of Oxygen Radicals. A. E. Taylor, S. Matalon, and P. A. Ward, editors. American Physiological Society, Bethesda, MD. 217-249. 
19. Itoh, M., and P. H. Guth. 1985. Role of oxygen derived free radicals in hemorrhagic shock-induced gastric lesions in the rat. Gastroenterology. 88:11621167.

20. Smith, S. M., M. B. Grisham, E. A. Manci, D. N. Granger, and P. R. Kvietys. 1987. Gastric mucosal injury in the rat: role of iron and xanthine oxidase. Gastroenterology. 92:950-956.

21. Smith, S. M., L. Holm-Rutili, M. A. Perry, M. B. Grisham, K. E. Arfors, D. N. Granger, and P. R. Kvietys. 1987. Role of neutrophils in hemorrhagic shock-induced gastric mucosal injury in the rat. Gastroenterology. 93:466-417.

22. Hassan, H. M. Biosynthesis and regulation of superoxide dismutase. Free Radicals Biol. Med. 5:377-385, 1988.

23. Heikkila, R. E., F. S. Cabbat, and G. Cohen. 1976. In vivo inhibition of superoxide dismutase in mice by diethyldithiocarbamate. J. Biol. Chem. 251:2182-2185.

24. Heikkila, R. E. 1985. Inactivation of superoxide dismutase by diethyldithiocarbamate. In Handbook of Methods for Oxygen Radical Research R. A. Greenwald, editor. CRC Press/Boca Raton, FL. 387-390.

25. Terano, A., K. J. Ivey, T. Stachura, S. Sekhon, H. Hosojima, W. N. McKenzie, W. J. Krause, and J. H. Wyche. 1982. Cell culture of rat gastric fundic mucosa. Gastroenterology. 83:1280-1291.

26. Thurman, R. G., H. G. Ley, and R. Scholz. 1972. Hepatic microsomal ethanol oxidation. Eur. J. Biochem. 25:420-430.

27. Homan-Muller, J. W. T., R. S. Weening, and D. Roos. 1975. Production of hydrogen peroxide by phagocytizing human granulocytes. J. Lab. Clin. Med. 85:198-207.

28. Beutler, E. 1975. Red cell metabolism. In A Manual of Biochemical Methods. Grune \& Statton, Inc., New York, NY. 69-73. 89-90.

29. Mannervik, B., and C. Gutenberg. 1981. Glutathione transferase. Meth ods Enzymol. 77:231-235.

30. Bradford, M. A. 1976. A rapid and sensitive method for the quantitation of microgram quantities of protein utilizing the principle of protein dye binding. Anal. Biochem. 72:248-254.

31. Tietze, F. 1969. Enzyme method for quantitative determination of nanogram amounts of total and oxidized glutathione. Anal. Biochem. 27:502-522.

32. Akerboom, T. P. M., and H. Sies. 1984. Assay of glutathione, glutathione disulfide, and glutathione mixed disulfides in biological samples. Methods Enzymol. 77:373-382.

33. Griffith, O. W. 1980. Determination of glutathione and glutathione disulfide using glutathione reductase and 2-vinylpyridine. Anal. Biochem. 106:207212.

34. Flohe, L., and F. Otting. 1984. Superoxide dismutase assays. Methods Enzymol. 105:93-104.

35. Ota, S., M. Razandi, S. Sekhon, W. J. Krause, A. Terano, H. Hiraishi, and K. J. Ivey. 1988. Salicylate effects on a monolayer culture of gastric mucous cells from adult rats. Gut. 29:1705-1714.

36. Hiraishi, H., A. Terano, S. Ota, K. J. Ivey, and T. Sugimoto. 1989. Regulation of prostaglandin production in cultured gastric mucosal cells. Prostaglandins. 38:65-78.

37. Margoliash, E., and A. Novogrodsky. 1958. Study of the inhibition of catalase by 3-amino-1,2,4-triazole. Biochem. J. 68:468-475.

38. Hiraishi, H., A. Terano, M. Razandi, T. Sugimoto, T. Harada, and K. J. Ivey. 1993. Role of iron and superoxide in mediating hydrogen peroxide injury to cultured rat gastric cells. Gastroenterology. 104:780-788.

39. Hiraishi, H., A. Terano, S. Ota, H. Mutoh, M. Razandi, T. Sugimoto, and K. J. Ivey. 1991. Role for iron in reactive oxygen species-mediated cytotoxicity to cultured rat gastric mucosal cells. Am. J. Physiol. 260:G556-563.

40. Keberle, H. 1964. The biochemistry of deferoxamine and its relation to iron metabolism. Ann. NY Acad. Sci. 119:758-768.

41. Halliwell, B., and J. M. C. Gutteridge. 1986. Oxygen free radicals and iron in relation to biology and medicine: some problems and concepts. Arch. Biochem. Biophys. 246:501-514.

42. Halliwell, B. 1989. Protection against tissue damage in vivo by desferrioxamine: what is its mechanism of action? Free Radicals Biol. Med. 7:645-651.

43. Nunez, M., E. S. Cole, and J. Glass. 1983. The reticulocyte plasma membrane pathway of iron uptake as determined by the mechanism of a,a'-dipyridyl inhibition. J. Biol. Chem. 258:1146-1151.

44. Minotti, G., and S. D. Aust. 1987. The requirement for iron (III) in the initiation of lipid peroxidation by iron (II) and hydrogen peroxide. J. Biol. Chem. 262:1098-1104.

45. Parks, D. A., and D. N. Granger. 1986. Xanthine oxidase: biochemistry, distribution and physiology. Acta Physiol. Scand. Suppl. 548:87-99.

46. Chambers, D. E., D. A. Parks, G. Patterson, R. Roy, J. M. McCord, S.
Yoshida, L. F. Parmley, and J. M. Downey. 1985. Xanthine oxidase as a source of free radical damage in myocardial ischemia. J. Mol. Cell. Cardiol. 17:145-152.

47. Kelner, M. J., and N. M. Alexander. 1986. Inhibition of erythrocyte superoxide dismutase by $N, N^{\prime}$-diethyldithiocarbamate also results in oxyhemoglobincatalyzed glutathione depletion and methemoglobin production. J. Biol. Chem. 261:1636-1641.

48. Kelner, M. J., R. Bagnell, B. Hale, and N. M. Alexander. 1989. Inactivation of intracellular copper-zinc superoxide dismutase by copper chelating agents without glutathione depletion and methemoglobin formation. Free Radicals Biol. Med. 6:355-360.

49. Trombetta, L. D., M. Toulon, and I. S. Jamall. 1988. Protective effect of glutathione on diethyldithiocarbamate cytotoxicity: a possible mechanism. Toxicol. Appl. Pharmacol. 93:154-164.

50. Bacon, B. R., and A. S. Tavill. 1984. Role of the liver in normal iron metabolism. Semin. Liver Dis. 4:181-192.

51. Haber, F., and J. Weiss. 1934. The catalytic decomposition of hydrogen peroxide by iron salt. Proc. R. Soc. Lond. A Math Phys. Sci. 147:332-351.

52. Halliwell, B. 1982. Superoxide-dependent formation of hydroxyl radicals in the presence of iron salts is a feasible source of hydroxyl radicals in vivo. Biochem. J. 205:461-462.

53. McCord, J. M., and I. Fridovich. 1968. Reduction of cytochrome $c$ by milk xanthine oxidase. J. Biol. Chem. 243:5753-5760.

54. Sutton, H. C., and C. C. Winterbourn. 1989. On the participation of higher oxidation states of iron and copper in Fenton reactions. Free Radicals Biol. Med. 6:53-60.

55. Winterbourn, C. C. 1979. Comparison of superoxide with other reducing agents in the biological production of hydroxyl radicals. Biochem. J. 182:625628

56. Kasai, H., and S. Nishimura. 1984. Hydroxylation of deoxyguanosine at the C-8 position by ascorbic acid and other reducing agents. Nucleic Acids Res. 12:2137-2145.

57. Van Steveninck, J. J., J. Van Der Zee, and T. M. A. R. Dubbelman. 1985. Site-specific and bulk-phase generation of hydroxyl radicals in the presence of cupric ions and thiol compounds. Biochem. J. 232:309-311.

58. Halliwell, B., and J. M. C. Gutteridge. 1985. The importance of free radicals and catalytic metal ions in human diseases. Mol. Aspects Med. 8:89-193.

59. Spragg, R. G., D. B. Hinshaw, P. A. Hyslop, I. U. Schraufstatter, and C. G. Cochrane. 1985. Alterations in adenosine triphosphate and energy charge in cultured endothelial and P388D, cells after oxidant injury. J. Clin. Invest. 76:14711476.

60. Andreoli, S. P., E. A. Leichty, and C. Mallett. 1990. Exogenous adenine nucleotides replete endothelial cell adenosine triphosphate after oxidant injury by adenosine uptake. J. Lab. Clin. Med. 115:304-313.

61. Roy, R. S., and J. M. McCord. 1983. Superoxide and ischemia: conversion of xanthine dehydrogenase to xanthine oxidase. In Oxy-Radicals and Their Scavenger System. II. Cellular and Medical Aspects, R. A. Greenwald, and G. Cohen, editors. Elsevier Science/North-Holland, New York. 145-153.

62. McCord, J. M., and R. S. Roy. 1982. The pathophysiology of superoxide: role of inflammation and ischemia. Can. J. Physiol. Pharmacol. 60:1346-1352.

63. Gutteridge, J. M. C., L. Maidt, and L. Poyer. 1990. Superoxide dismutase and Fenton chemistry. Reaction of ferric-EDTA complex and ferric-bipyridyl complex with hydrogen peroxide without the apparent formation of iron (II). Biochem. J. 269:169-174.

64. Hiraishi, H., A. Terano, S. Ota, K. J. Ivey, and T. Sugimoto. 1987. Oxygen metabolite-induced cytotoxicity to cultured rat gastric mucosal cells. Am. J. Physiol. 253:G40-G48.

65. Takahashi, M., and K. Asada. 1983. Superoxide anion permeability of phospholipid membranes and chloroplast thylakoids. Arch. Biochem. Biophys. 226:558-563.

66. Starke, P. E., and J. L. Farber. 1985. Ferric iron and superoxide are required for the killing of cultured hepatocytes by hydrogen peroxide. J. Biol. Chem. 260:10099-10104.

67. Kyle, M. E., D. Nakae, I. Sakaida, S. Miccadei, and J. L. Farber. 1988. Endocytosis of superoxide dismutase is required for the enzyme to protect hepatocytes from the cytotoxicity of hydrogen peroxide. J. Biol. Chem. 263:37843789.

68. Freeman, B. A., S. L. Young, and J. D. Crapo. 1983. Liposome-mediated augmentation of superoxide dismutase in endothelial cells prevents oxygen injury. J. Biol. Chem. 258:12534-12542.

69. Fuchs, H. J. R., and C. L. Borders, Jr. 1983. Affinity inactivation of bovine $\mathrm{Cu}, \mathrm{Zn}$ superoxide dismutase by hydroperoxide anion, $\mathrm{HO}_{2}^{-}$. Biochem. Biophys. Res. Commun. 116:1107-1113. 